\title{
THE EFFECT OF SELF-EFFICACY FINANCIAL MEDIATION ON FACTORS AFFECTING FINANCIAL INCLUSION IN SMALL BUSINESSES IN WEST JAKARTA
}

\author{
Najib Arafat, Farah Margaretha Leon \\ Fakultas Ekonomi Dan Bisnis - Universitas Trisakti \\ Jalan Kyai Tapa No 1 Grogol Jakarta \\ farahmargaretha@trisakti.ac.id ${ }^{2}$
}

\begin{abstract}
This study aims to examine and analyze the effect of financial self-efficacy mediation on the factors that influence financial inclusion in small businesses in West Jakarta. The dependent variables used in this study are commercial attitude and financial literacy, financial inclusion as an independent variable, and financial self-efficacy as a mediating variable. The sample of this study used 176 respondents who used a purposive sampling method. The data analysis model used is structural equation modeling (SEM). The results of this study indicate that financial attitude has a positive influence on financial inclusion. Financial literacy does not have a positive impact on financial inclusion. Financial position has a positive effect on financial inclusion that is mediated by financial self-efficacy. Financial self-efficacy does not mediate the impact of financial literacy on financial inclusion. This means that attitudes and self-confidence of commercial consumers increase access to formal financial services. This research implies that financial managers and the government need to create a sense of security and comfort for small business activists who want to use formal financial institutions, and the government also needs to make regulations and policies that support increased productivity in the use of financial services legal.
\end{abstract}

Keywords: financial self-efficacy, financial inclusion, financial knowledge, financial attitudes

\begin{abstract}
Abstrak
Penelitian ini bertujuan untuk menguji dan menganalisis pengaruh mediasi self-efficacy keuangan pada faktor-faktor yang mempengaruhi inklusi keuangan dalam usaha kecil di Jakarta Barat. Variabel dependen yang digunakan dalam penelitian ini adalah sikap komersial dan literasi keuangan, inklusi keuangan sebagai variabel independen, dan self-efficacy keuangan sebagai variabel mediasi. Sampel penelitian ini menggunakan 176 responden yang menggunakan metode purposive sampling. Model analisis data yang digunakan adalah pemodelan persamaan struktural (SEM). Hasil penelitian ini menunjukkan bahwa sikap keuangan memiliki pengaruh positif terhadap inklusi keuangan. Literasi keuangan tidak memiliki dampak positif pada inklusi keuangan. Posisi keuangan memiliki efek positif pada inklusi keuangan yang dimediasi oleh self-efficacy keuangan. Kemandirian finansial tidak memediasi dampak literasi keuangan pada inklusi keuangan. Ini berarti bahwa sikap dan kepercayaan diri konsumen komersial meningkatkan akses ke layanan keuangan formal. Penelitian ini menyiratkan bahwa manajer keuangan dan pemerintah perlu menciptakan rasa aman dan nyaman bagi para aktivis bisnis kecil yang ingin menggunakan lembaga keuangan formal, dan pemerintah juga perlu membuat peraturan dan kebijakan yang mendukung peningkatan produktivitas dalam penggunaan jasa keuangan. hukum.
\end{abstract}

Kata kunci: self-efficacy keuangan, inklusi keuangan, pengetahuan keuangan, sikap keuangan

\section{Introduction}

According to the Law of the Republic of Indonesia No 20 of 2008 concerning Micro, Small, and Medium Enterprises, article 1 reads that small business are small-scale economic activities of the people with business sectors which are predominantly small business activities and need to be protected to prevent from the unfair business competition. According to Law no. 9 of 1995 the criteria for small businesses are: Having a net worth of at most Rp200,000,000,- (Two Hundred Million Rupiah) excluding land and buildings where the company is located, having annual sales results 
of at most Rp1,000,000,000,- (One Billion Rupiah), owned by Indonesian citizens, selfreliant which is not a subsidiary or branch company that is not owned, controlled, or affiliated directly or indirectly with medium or large businesses, in the form of individual companies, business entities that is not a legal entity or a business entity that is a legal entity, including cooperatives.

Indonesia is included in a country with a high level of financial exclusion, as seen from the results of several surveys conducted by several national and international institutions. Bank Indonesia (2011), through the Household Balance Sheet Survey, shows that the percentage of families that have savings in formal and informal financial institutions is $48 \%$ so that people who have no savings at all in formal or informal financial institutions are still very high namely by $52 \%$. While a survey conducted by the World Bank (2014) shows that only $36 \%$ of Indonesian people over the age of 15 have access to formal and informal financial institutions. The inability of individuals to participate voluntarily or involuntarily access precise financial services has been identified as a significant barrier to socio-economic development in developing countries (Demirguc and Klapper, 2012). Lakshmi and Visalakshmi (2013), defines financial inclusion as a process of ensuring access to timely and adequate financial and credit services if needed by vulnerable groups such as weaker groups and low-income groups at affordable costs.

Attitudes that are a desire to save borrow, or use insurance products, affect financial inclusion among poor households in low-income countries (Holzmann, 2010). The assumption underlying the concept of attitude is that attitudes guide, influence, direct, shape and predict actual behavior. Therefore, it is anticipated that through a deliberative process, financial consumers evaluate and assess whether the use of financial services is essential to improve their welfare or not (Fisben and Ajzen, 2011). This study aims to examine and analyze the effect of financial self-efficacy mediation on the factors that influence financial inclusion in small businesses in West Jakarta.

\section{Literature Review}

The variables that will be discussed in this study are financial attitude, financial literacy, financial self-efficacy, and financial inclusion.

\section{Financial Attitude}

Financial attitude is a state of mind, opinions, and judgments about finance (Klontzet at, 2011). Individuals with a high level of financial attitude are more likely to have a positive attitude towards a plan (Mindra and Moya, 2017). Agarwalla, Barua, Jacob, and Varma (2015), in their research in a country, mentioned that almost half of the working youths showed a high financial attitude towards their financial planning and had a low tendency towards consumption.

\section{Financial Literacy}

Financial literacy is the ability to make informed judgments and make effective decisions about the use and management of money (Bhushan and Meduri, 2013). Financial literacy brings benefits to individuals and families because there is increasing evidence that people with a high level of financial education can manage their money better, participate in the stock market and achieve better returns on the investments they make (Allgood and Walstad, 2016).

\section{Financial Self-Efficacy}

Self-efficacy is a widely accepted foundation in the theory of social cognition, although it has offered relevant and valuable research insights in various organizational contexts such as entrepreneurship, safety, and self-service (Drnovsek, Wincent, and Cardon, 2010). Self-efficacy plays a vital role in guiding individual trust through rehabilitation and optimizing performance (Zach, Dobersek, Filho, Inglish, and Tannenbaum, 2018). Financial selfefficacy will benefit society as they explore the reasons some people manage to manage their finances while possessing demographic characteristics and the same economy was unsuccessful (Lown, 2011).

\section{Financial Inclusion}

Lakshmi and Visalakshmi (2013), define financial inclusion as a process of ensuring timely and adequate access to financial and credit services if needed by vulnerable groups such as weaker groups and low-income groups 
at affordable costs. Financial inclusion is the process of receiving or providing financial services and products at affordable prices (Lakshmi and Visalakshmi, 2013). Financial inclusion connects individuals, especially the poor and vulnerable groups, to the formal banking system with safe, easy and affordable access to credit and other financial services (Sarma and Pais, 2011).

\section{Research framework}

Lakshmi and Visalakshmi (2013), define financial inclusion as a process of ensuring timely and adequate access to financial and credit services if needed by vulnerable groups such as weaker groups and low-income groups at affordable costs. Financial inclusion connects individuals, especially the poor and vulnerable groups, to the formal banking system with safe, easy and affordable access to credit and other business services (Sarma and Pais, 2011).

Complications of financial planning and counseling scales suggest the need for financial self-efficacy scales (Grable, Archuleta, and Nazarinia, 2010). Lown (2011) explains the relationship between the principle of selfefficacy and higher levels of well-being. Kinard and Webster (2010), in their study, telling the relationship between self-efficacy and consumption behavior, found that self-efficacy was a weak predictor of risk behavior.

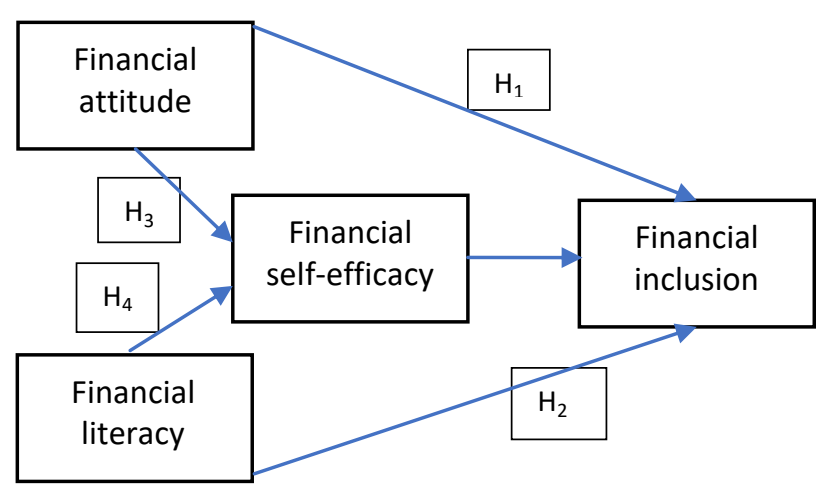

Figure 1

\section{Conceptual Framework Scheme}

Individuals with a high level of financial attitude are more likely to have a positive attitude towards a plan (Mindra and Moya, 2017). Agarwalla, Barua, Jacob, and Varma (2015), in their research in a country, mentioned that almost half of the working youths showed a high financial attitude towards their financial planning and had a low tendency towards consumption. Huston (2010) explains that factors such as habits, cognitive, economic, family, peers, community, and institutions can have an impact on financial behavior. Financial literacy brings benefits to individuals and families because there is increasing evidence that people with a high level of financial education can manage their money better, participate in the stock market and achieve better results from the investments they make (Allgood and Walstad, 2016).

\section{Hypothesis Development}

The assumption underlying the concept of attitude is that attitudes guide, influence, direct, shape, and predict actual behavior. Therefore it is anticipated that through a deliberative process, financial consumers evaluate and assess whether the use of financial services is essential to improve their welfare or not (Fisben and Ajzen, 2011). It is said that attitudes towards money and finance will influence individual behavior towards savings, loans, and risk-taking (Agarwalla, Barua, Jacob and Varna, 2015). Anxiety predicts conservative financial decisions and is associated with decisions not to invest in savings but instead to hold interest-bearing accounts and with low predictability of stock trends (Paluri and Mehra, 2016). Financial motives, financial literacy, and economic attitudes influence individual financial behavior and can be chosen as a variable for market segmentation for financial products. Financial motifs refer to the reasons for buying financial products. Based on the explanation above, the hypothesis can be formulated as follows:

\section{$H_{1}$ : There is a positive influence between financial attitude and financial inclusion.}

Financial literacy, in addition to increasing the ability of individuals to make financial decisions, also increases selfconfidence. Thus increasing one's ability to comfortably access and use formal financial services (Atkinson and Messy, 2012). Several potential financial consumers do not have relevant knowledge about the financial concepts and skills needed to facilitate their choices and decisions are most useful for improving their quality of life and well-being (Lusardi and Mitchell, 2013). The emphasis on 
financial literacy in several countries has generated a lot of attention and has grown in recent years. Due to the complexity that arises in the dynamic financial industry which requires commercial consumers to be more active in making financial choices and decisions (Mindra and Moya, 2017). Based on the explanation above, the hypothesis can be formulated as follows:

$\mathrm{H}_{2}$ : There is a positive influence between financial literacy and financial inclusion.

One of the main factors influencing financial behavior is self-efficiency, which is described as the level of trust in a financial ability to handle financial situations without being overwhelmed (Amatucci and Crawley, 2011). Madra and Moya (2017) say that selfefficacy in different domains indirectly plays a facilitative role in the process of cognitive involvement to realize more successful performance driven by the willingness to achieve success in addition to the skills they have. In line with this, self-efficacy has been used in several studies as a mediating variable and has been identified as a distant predictor more consistent than behavior and behavior change (Mindra and Moya, 2017). In analyzing one's financial behavior, there is scope for economic models to fully incorporate psychometric instruments that capture the confidence of individuals in controlling their financial management capacity. Ka, so as to produce a complete picture of the factors that contribute to their financial results (Xiao, 2008). At present, a detailed discussion of financial self-efficacy is almost non-existent, given the fact that in other fields, self-efficacy has been found to have a positive mediation and moderation relationship on individual attitudes and behavior. Based on the explanation above, the hypothesis can be formulated as follows:

\section{$\mathrm{H}_{3}$ : Financial self-efficacy mediates the effect between financial perspective and financial inclusion.}

\section{$\mathrm{H}_{4}$ : Financial self-efficacy mediates the effect of financial literacy and financial inclusion.}

\section{Research Methodology}

The data used in this study are primary data obtained from questionnaires distributed to respondents who meet the requirements, namely respondents who have a savings account book no more than once and have a small business unit such as culinary, grocery, and street vendors. The questionnaire was distributed as many as 250 questionnaires, but before distributing the questionnaire a pre-test was carried out to 50 respondents to get responses and criticisms and suggestions related to our questionnaire, if the questionnaire was understood by respondents then distributed to respondents selected as samples. Direct survey. The analytical tool that will be used is SEM, then the recommended sample in this study is 100 - 400 samples (Hair et al., 2018). The number of samples taken from the population is determined at 10 times the number of items used to measure the variables used in the analysis design, and at least 120 samples (Hair et al., 2018).

The technique used in this data collection was purposive sampling. The sample for the observation unit in this study were individuals who had no more than one bankbook and small business. In this study, there are four variables, namely: financial attitude and financial literacy as independent variables, financial inclusion as dependent variables, financial self-efficacy as moderating variables. There are three variables, namely financial attitude, financial self-efficacy, and financial inclusion using the type of interval scale that is the Likert scale which is a measurement technique using a 5 point scale where 1 = Strongly Disagree, $2=$ Disagree, 3 = Agree Agree, $4=$ Agree, and $5=$ Strongly Agree, while one variable which is financial literacy is measured from the questions raised by Atkinson and Messy (2012). This section uses measurement by scoring or assessment based on the number of questions answered correctly by the respondent. The number of correct answers will be calculated and divided by all questions and then multiplied by one hundred percent. Respondents' answers were then divided into 3 categories, namely (1) $<60 \%$ which means that individuals have low financial knowledge, (2) $60 \%-79 \%$, which means individuals have knowledge of moderate finance, and (3) $>80 \%$ which shows that 
individuals have high financial knowledge (Farah and Reza, 2015). The ratio scale used is reduced to the Likert size by calculating the number of correct answers divided by the number of questions multiplied by 100 , then the score is as follows: (1) $0-20=$ Do not really understand, (2) $21-40=$ Do not understand, (3) 41 - 60 = Understand enough, (4) $61-80=$ understand, and (5) $81-100=$ Very understand.

The research instrument test used was in the form of a questionnaire that was completed by the respondent, which was then examined for its validity by conducting a research instrument test for each statement in the survey and respondent. The research instrument test was in the form of a validity test and a reliability test with the following explanation:

1. A validity test is a test conducted to find out whether a measurement instrument is considered good and can be used to measure the relevant variables (Sekaran and Bougie, 2016). The validity test uses factor analysis by looking at the loading factor of the sample used is 176 , then the loading factor is required to be worth $\geq$ 0.40 to be declared a valid instrument (Hair et al., 2018). As for financial literacy variables using Pearson analysis, by looking at the $R$ table of the sample used is 176 , then the $R$ table is required to have a value $\geq 0.148$, to be needed as a valid instrument.

2. A reliability test is a test conducted to measure the consistency between indicators in measuring a variable (Sekaran and Bougie, 2016). Reliability testing is done by looking at the Cronbach's alpha value of each variable with the decision making criteria that the variable instrument is considered reliable if the Cronbach's alpha value is $\geq 0.6$ (Hair et al., 2018). Whereas for financial literacy, variables cannot be tested for validity because financial literacy variables are considered only to have 1 indicator.

The data analysis method used is the Structural Equation Model (SEM) with the help of the Analysis of Moment Structure (AMOS) 22 program. SEM is a statistical technique that allows testing a series of relationships simultaneously to analyze the involvement of influence from various variables. Before testing a hypothesis, it is necessary first to test the model used by examining the model's suitability or goodness of fit test. The goodness of fit test is a test conducted to measure the adequacy of the model used in research with data obtained (Hair et al., 2018). Types of the goodness of fit measurement, according to Ghozali \& Fuad (2017), namely:

1. The absolute fit measure used to measure the overall fit model (both structural models and measurement models simultaneously). The criteria are to look at the probability value, and the root means the square error of approximation (RMSEA).

2. The incremental fit measure is a measure used to compare proposed models with other models specified by researchers. The criteria are by looking at the normed fit index (NFI), the turtle-lewis Index (TLI), the comparative fit index (CFI), and the Incremental Fit Index (IFI).

3. Parsimonious fit measure, which is an adjustment to the measurement of fit to be compared between models with several different coefficients. The criteria are by looking at the value of Normed Chi-Square (CMIN).

\section{Analysis and Discussion Descriptive statistics}

Descriptive statistical analysis is used to provide a description or description of data. In this study, descriptive statistics used are mean values and standard deviations. The mean value indicates the average assessment done by the respondent on the variable under investigation, while the standard deviation suggests variations in the answers given by the respondent. If the standard deviation is given is close to zero, the less homogeneous the answers provided by the respondent, but if the standard deviation is given away from zero, the respondent's answers will vary more.

\section{Hypothesis test}

After testing the suitability of the model, it was found that the model turned out to be feasible for hypothesis testing. Hypothesis decision making is done by comparing the $p$ value with a significance level of 0.05 (error rate $\alpha=5 \%$ ) and a $95 \%$ confidence level. The basis of hypothesis decision making is as 
follows: (a) If the $\mathrm{p}$-value $\leq 0.05$, then $\mathrm{H}_{0}$ is rejected, which means there is a significant influence of both variables. (b) If the $p$-value $\geq$ 0.05 , then $H_{0}$ fails to reject ( $H_{0}$ is accepted), which means there is no significant effect of the two variables.

Table 1

Descriptive Statistics of Financial Inclusion

\begin{tabular}{lcc}
\hline \multicolumn{1}{c}{ Indicator } & Mean & $\begin{array}{c}\text { Standard } \\
\text { deviation }\end{array}$ \\
\hline There is an access road that can be used towards the & 4.24 & 0.687 \\
nearest formal financial institution. & 4.36 & 0.780 \\
The nearest bank is less than 5km from my house. & 4.14 & 1.029 \\
$\begin{array}{l}\text { I live less than 1km from the nearest ATM. } \\
\text { There is an access road that can be used to get to the }\end{array}$ & 4.29 & 0.685 \\
nearest financial institution. & & 0.767 \\
I understand formal financial products and services & 4.01 & 0.706 \\
(savings, loans, insurance, and payment/remittances). & 4.21 & 0.671 \\
$\begin{array}{l}\text { I use my savings account for my future expenses. } \\
\text { I know which documents are needed to open an }\end{array}$ & 4.23 & 0.773 \\
account. & 4.24 & 0.5065675 \\
\hline I received fast information about my transaction. & 4.2152 & \\
Financial Inclusion
\end{tabular}

Source: data processed using SPSS (attached)

Table 2

Descriptive Financial Statistics Attitude

\begin{tabular}{|c|c|c|}
\hline Indicator & Mean & $\begin{array}{l}\text { Standard } \\
\text { Deviation }\end{array}$ \\
\hline $\begin{array}{l}\text { I am considering using formal financial services (savings, } \\
\text { loans, insurance, and payment/shipping) that are useful. }\end{array}$ & 4.15 & 0.876 \\
\hline $\begin{array}{l}\text { I feel comfortable using a money transfer service to send } \\
\text { and receive money. }\end{array}$ & 4.23 & 0.746 \\
\hline $\begin{array}{l}\text { In my opinion, using formal financial services is safe for } \\
\text { a business transaction. }\end{array}$ & 4.20 & 0.679 \\
\hline It is wise to borrow money from formal financial services. & 3.98 & 0.962 \\
\hline Financial attitude & 4.140625 & 0.6254475 \\
\hline
\end{tabular}

Source: data processed using SPSS (attached)

Table 3

Descriptive Statistics of Variable Financial Self-Efficacy

\begin{tabular}{lcc}
\hline \multicolumn{1}{c}{ Indicator } & Mean & $\begin{array}{c}\text { Standard } \\
\text { Deviation }\end{array}$ \\
\hline I am sure that I can manage my finances. & 4.18 & 0.739 \\
I can easily spend money, less than my monthly income. & 3.79 & 0.886 \\
I believe I can deposit money in the bank to plan my & 4.31 & 0.707 \\
future. & 3.60 & 1.064 \\
I can borrow money from banks. & 3.96 & 0.824 \\
I have what it takes to use financial services to manage & 3.96704 & 0.589474 \\
my financial goals. & & \\
Financial self-efficacy
\end{tabular}

Source: data processed using SPSS (attached) 
Table 4

Descriptive Statistics Variable financial literacy

\begin{tabular}{|l|l|l|}
\hline \multicolumn{1}{|c|}{ Variable } & \multicolumn{1}{|c|}{ Mean } & \multicolumn{1}{c|}{$\begin{array}{l}\text { Standard } \\
\text { deviation }\end{array}$} \\
\hline $\begin{array}{l}\text { Financial } \\
\text { literacy }\end{array}$ & 3.7102 & 0.95684 \\
\hline
\end{tabular}

Source: data processed using SPSS (attached)

The purpose of testing the hypothesis is to answer the problems raised in the study by rejecting the null hypothesis $\left(\mathrm{H}_{0}\right)$ so that the alternative hypothesis $\left(\mathrm{H}_{\mathrm{a}}\right)$ can be accepted. This can be done by looking at the significance value of each effect of the variables proposed in the study. The results of hypothesis testing are presented in the table below:

Table 5

Hypothesis Testing Results

\begin{tabular}{|c|c|c|c|}
\hline Hypothesis & $\begin{array}{c}\text { Estima } \\
\text { te }\end{array}$ & p-value & Decision \\
\hline $\begin{array}{l}\mathrm{H}_{1} \text { : There is a } \\
\text { positive influence } \\
\text { between financial } \\
\text { attitude and } \\
\text { financial inclusion. }\end{array}$ & 0.643 & 0.000 & $\begin{array}{l}\text { Ho } \\
\text { rejected }\end{array}$ \\
\hline $\begin{array}{l}\mathrm{H}_{2} \text { : There is a } \\
\text { positive influence } \\
\text { between financial } \\
\text { literacy and } \\
\text { financial inclusion. }\end{array}$ & 0.014 & 0.314 & $\begin{array}{l}\text { Ho } \\
\text { accepted }\end{array}$ \\
\hline
\end{tabular}

Table 6

Results of the Intervening Hypothesis Testing
Model $\quad$ Estimate p-

\begin{tabular}{|c|c|c|c|}
\hline & & value & \\
\hline \multicolumn{4}{|l|}{ Model 1} \\
\hline $\begin{array}{l}\text { There is an } \\
\text { effect } \\
\text { financial attitude }\end{array}$ & 0.643 & 0.000 & $\begin{array}{l}\text { There is a } \\
\text { positive } \\
\text { influence }\end{array}$ \\
\hline $\begin{array}{l}\text { on financial } \\
\text { inclusion. } \\
\text { Model } \mathbf{2}\end{array}$ & & & \\
\hline $\begin{array}{l}\text { There is an } \\
\text { effect of } \\
\text { financial attitude } \\
\text { on financial self- } \\
\text { efficacy. }\end{array}$ & 0.594 & 0.000 & $\begin{array}{l}\text { Requirements } \\
\text { (a) are } \\
\text { fulfilled. }\end{array}$ \\
\hline $\begin{array}{l}\text { There is an } \\
\text { effect } \\
\text { financial self- }\end{array}$ & 0.347 & 0.002 & $\begin{array}{l}\text { Requirements } \\
\text { (b) are } \\
\text { fulfilled. }\end{array}$ \\
\hline $\begin{array}{l}\text { efficacy on } \\
\text { financial } \\
\text { inclusion. }\end{array}$ & & & \\
\hline $\begin{array}{l}\text { There is an } \\
\text { effect } \\
\text { financial attitude }\end{array}$ & 0.648 & 0.000 & $\begin{array}{l}\text { Requirements } \\
\text { (c) fulfilled } \\
\text { (being partial }\end{array}$ \\
\hline on financial & & & significant) \\
\hline
\end{tabular}

\begin{tabular}{l} 
Model Estimate $\begin{array}{c}p- \\
\text { value }\end{array}$ \\
\hline inclusion. \\
$\mathrm{H}_{3}$ : Financial self-efficacy \\
mediates the effect between \\
financial attitude and financial \\
inclusion.
\end{tabular}

Source: data processed using SPSS (attached)

Table 7

Results of the Intervening Hypothesis Testing

\begin{tabular}{lccc}
\hline \multicolumn{1}{c}{ Model } & Estimate & $\begin{array}{c}\boldsymbol{p} \text { - } \\
\text { value }\end{array}$ & Conclusion \\
\hline $\begin{array}{l}\text { Model 1 } \\
\text { There is an } \\
\text { influence of } \\
\text { financial literacy }\end{array}$ & 0.014 & 0.0045 & $\begin{array}{c}\text { There is a } \\
\text { positive } \\
\text { influence. }\end{array}$
\end{tabular}

inclusion.

\section{Model 2}

$\begin{array}{llll}\text { There is an } & 0.059 & 0.0695 & \text { Requirements }\end{array}$ influence of $\quad$ (a) are not financial literacy fulfilled.

on financial self-efficacy.

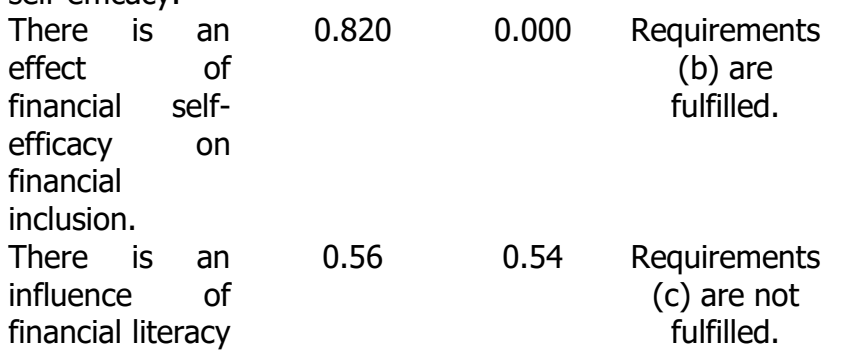

on financial

inclusion.

$\mathrm{H}_{4}$ : Financial self-efficacy mediates Ho the effects of financial literacy and accepted financial inclusion.

Source: data processed using SPSS (attached)

\section{Discussion of Research Results Hypothesis 1}

The first hypothesis in this study examines the effect of financial attitudes on financial inclusion. The results of the research that have been done show that there is a positive effect of financial attitude on financial inclusion as indicated by a p-value of $0.000 \leq$ 0.05 , meaning the results of this study do not support the results of previous studies 
conducted by Mindra and Moya (2017) but supported by previous research conducted by Fishbein and Ajzen (2011) which states that when individuals evaluate a behavior or attitude that benefits them to achieve specific results, it will direct individuals to the involvement of their action that affects access on the use of financial services and will increase financial inclusion.

\section{Hypothesis 2}

The second hypothesis in this study examines the effect of financial literacy on financial inclusion. The results of the research that have been done show that there is no positive effect of financial literacy on financial inclusion as indicated by a p-value of $0.314 \geq$ 0.05 , meaning the results of this study do not support the results of previous studies that conducted by Mindra and Moya (2017). So from that level of financial literacy, understanding that is on the trader does not affect the level of financial inclusion in the area, which means the results of this study do not support the results of previous studies conducted by Mindra and Moya (2017). Product and financial services inherently improve and become more complex without being followed by a corresponding growth in the level of financial literacy in several classes in the community order based on Mindra and Moya (2017).

\section{Hypothesis 3}

The third hypothesis in this study examines financial self-efficacy mediating the effect between financial attitude and financial inclusion. The results of the research that have been done show that financial self-efficacy partially mediates the impact between financial attitude and financial inclusion shown in table 12 can be seen that in model one there is an influence of financial attitude on financial inclusion ( $p$-value $=0,000)$, and becomes partially significant in model two ( $p$-value $=$ 0,000 ; meeting $c$ requirements), and the condition that there is an effect of financial attitude on financial towards financial selfefficacy ( $p$-value $=0,000$; terms of a) and the condition that there is an effect of financial selfefficacy on financial inclusion ( $p$-value $=0.002$; condition $b$ ) is also fulfilled in model two which means the results of this study do not support the results of previous studies conducted by Mindra and Moya (2017). Based on this third hypothesis, financial attitude will increase financial inclusion through financial selfefficacy. In line with research conducted by Amatucci and Crawley (2011) which states that one of the factors that influence financial behavior is self-efficacy, which is described as the level of trust in one financial ability without being overwhelmed.

\section{Hypothesis 4}

The fourth hypothesis in this study examines financial self-efficacy mediating the effect between financial literacy and financial inclusion. The results of research that have been done show that financial self-efficacy does not mediate the impact of financial literacy on financial inclusion shown in table 13 can be seen that in model one there is an effect of financial literacy on financial inclusion ( $p$-value $=0.0045)$, and it becomes insignificant in model two ( $p$-value $=0.54$; does not meet the conditions $c$ ), the situation there is an effect of financial literacy on financial self-efficacy ( $p$ value $=0.0695$; conditions $a$ ) are not met and the terms for financial self-efficacy to financial inclusion ( $p$-value $=0.002$; conditions $b$ ) are met in model two. The results of this study do not support the results of previous studies conducted by Mindra and Moya (2017). So from that, the financial knowledge or financial literacy of the respondents, even though selfconfidence or financial self-efficacy does not increase their financial inclusion. Based on the results of the fourth hypothesis, it turns out financial self-efficacy does not mediate the effect between financial literacy and financial inclusion due to differences in the demographic factors of the respondents conducted by previous researchers and this research. Lyons (2005) shows that financial products and services are inherently increased and become more complex without being followed by growth, which is commensurate in the level of financial literacy in several classes in the public order.

\section{Conclusions, Managerial Implications, Limitations And Suggestions Conclusions}

The results of research conducted on the effect of financial attitude and financial literacy on financial inclusion mediated by financial self- 
efficacy in small businesses in West Jakarta will be described as follows: (1). Financial attitude has a positive effect on financial inclusion. This means that the better financial attitude of a trader can increase financial inclusion in the area; (2). Financial literacy does not have a positive influence on financial inclusion. This means that the level of financial knowledge of small business activists does not affect the financial inclusion of small business activists; (3). Financial attitude has a positive influence on financial inclusion mediated by financial selfefficacy. This means that if the financial attitude of the traders is good it will increase financial inclusion in the area and financial selfefficacy will make traders feel the financial attitude of the formal financial institutions is good and will increase financial inclusion in the area; (3) Financial self-efficacy does not mediate the effect of financial literacy on financial inclusion. This means that the level of financial knowledge of small business activists does not affect the financial inclusion of small business activists even through financial selfefficacy.

\section{Managerial Implications}

Based on the results of research that has been done, several managerial implications can be done to the government as follows:

1. Managers of formal financial institutions need to create a sense of security and comfort for small business activists who want to use legal, financial institutions. What can be done is to improve service products that are useful for small business activists and also increase the transaction security of small business activists that have been carried out so that these small business activists have good attitudes and views towards formal financial institutions and are expected not to switch to using institutions non-formal finance.

2. The government also needs to make regulations and policies that support increased productivity in the use of formal financial services. Such as making policies to ensure the security of transactions and also strategies to improve customer services informal financial institutions. It is expected that these small business activists have an excellent financial attitude with the regulations and policies that make these small business activists plan to use formal financial services.

\section{Research Limitations}

This study has limitations such as this study only examined the effect of financial attitude and financial inclusion as variables that affect financial inclusion through financial selfefficacy.

\section{Suggestion}

Based on some of the limitations of the above research, the opinions and recommendations that can be submitted for further study, the researcher can then include other variables such as locus of control as variables that mediate the effect of financial literacy on financial inclusion (Ida and Cyintia, 2010).

\section{References}

Ahlin, B., Drnovsek, M. and Hisrich, R. (2014), "Entrepreneurs' creativity and firm innovation: the moderating role of entrepreneurial self-efficacy," Small Business Economics, Vol. 43 No. 1, pp. 101-17.

https://doi.org/10.1007/s11187-013$\underline{9531-7}$

Allgood, S. and Walstad, W.B. (2016), "The effects of perceived and actual financial literacy on financial behaviors," Economic Inquiry, Vol. 54 No. 1, pp. 675-697. https://doi.org/10.1111/ecin.12255

Agarwal, S., Driscoll, J., Gabaix, X., Laibson, D. (2009). The age of reason: financial decisions over the lifecycle and implications for regulation. Brookings Papers on Economic Activity 2, 51-117. https://dash.harvard.edu/bitstream/han dle/1/4554335/Laibson AgeofReason.pd f?sequence $=2$

Agarwalla, S.K., Barua, S.K., Jacob, J. and Varna, J.R. (2015), "Financial literacy among working young in urban India," Working Paper No. 2013-10-02, IIM, Ahmedabad, pp. 1-27. 
https://doi.org/10.1016/j.worlddev.2014 .10 .004

Amatucci, F.M., and Crawley, D.C. (2011), "Financial self-efficacy among women entrepreneurs," International Journal of Gender and Entrepreneurship, Vol. 3 No. 1 , pp. 23-37. https://doi.org/10.1108/1756626111111 $\underline{4962}$

Atkinson, A. and Messy, F.-A. (2012), "Assessing financial literacy in 12 countries: an OECD/INFE international pilot exercise", Journal of Pension Economics and Finance, Vol. 10 No. 4, pp.

665.https://doi.org/10.1017/S14747472 $\underline{11000539}$

Bank Indonesia. (2014). Booklet Financial Inclusion. Jakarta: Bank Indonesia

Bhushan, P., \& Medury, Y. (2013). Financial literacy and its determinants. International Journal of Engineering, Business, and Enterprise Applications (IJEBEA), 4(2), 155-160. https://www.researchgate.net/profile/Pu neet Bhushan/publication/264355562 Fi nancial literacy and its determinants/li nks/53da1c1c0cf2631430c7f721.pdf

Drnovsek, M., Wincent, J. and Cardon, M. (2010), "Entrepreneurial self-efficacy and business start-up: developing a multi-dimensional definition," International Journal of Entrepreneurial Behaviour and Research, Vol. 16 No. 4, pp. 329-48. https://doi.org/10.1108/1355255101105 $\underline{4516}$

Farah, M., dan Reza, A.P. (2015), Tingkat literasi keuangan pada mahasiswa S-1 Fakultas Ekonomi. Jurnal manajemen, Vol. $17 \quad$ No. 1. https://doi.org/10.9744/jmk.17.1.76-85

Fishbein, M. and Ajzen, I. (2011), Predicting and Changing Behavior: The Reasoned Action Approach, Taylor \& Francis, Reading, MA.
Ghozali, I dan Fuad. (2017). Structural Equation Modeling: Teori, Konsep, dan Aplikasi, $7^{\text {th }}$ ed., Semarang: Badan Penerbit Universitas Diponegoro.

Hair, J.F., Anderson, R.E., Tatham, R.L. and Black, W.C. (2018), Multivariate Data Analysis, 8th ed., Prentice-Hall, Englewood Cliffs, NJ.

Holzmann, R. (2010), "Bringing financial literacy and education to low and middle-income countries: the need to review, adjust, and extend current wisdom," World Bank, IZA and CES, Washington DC,

Huston, S.J. (2010), "Measuring financial literacy," Journal of Consumer Affairs, Vol. 44 No. 2, pp. 296316.https://doi.org/10.1111/j.1745$\underline{6606.2010 .01170 . x}$

Kinard, B. R. \& Webster, C. (2010). The Effects of Advertising, Social Influences, and Self-Efficacy on Adolescent Tobacco Use and Alcohol Consumption. Journal of Consumer Affairs, 44, 24-43. https://doi.org/10.1111/j.1745$\underline{6606.2010 .01156 . x}$

Klontz, B, Beitt, S. L, Mentzer, J. \& Klontz, T. (2011) "Money Beliefs and Financial behaviors: Development of the Klontz Money Script Inventory." The Journal of Financial

Therapy, 2(1).https://doi.org/10.4148/jft.v2i1.451

Lakshmi, P., and Visalakshmi, S. (2013). "Impact of Cooperatives in Financial Inclusion \& Comprehensive Development," Journal of Finance and Economics, Vol. 1, No. 3, pp. 49-53. http://pubs.sciepub.com/jfe/1/3/4/index .html

. Lown, J. (2011). Outstanding AFCPE $®$ Conference Paper: Development and Validation of a Financial Self- Efficacy Scale, Journal of Financial and Planning, Vol.22, No.2, p. 54, https://ssrn.com/abstract $=2006665$ 
Lusardi, A. and Mitchell, O.S. (2013), "The economic importance of financial literacy: theory and evidence," Working Paper Series No. 2014-001, GFLEC, Washington, DC

Lusardi, A., Mitchell, O.S. and Curto, V. (2010), "Financial literacy among the young," The Journal of Consumer Affairs, Vol. 44 No. 2, pp. 358-380. https://doi.org/10.1111/j.17456606.2010.01173.x

Mindra, R., \& Moya, M. (2017) "Financial selfefficacy: a mediator in advancing financial inclusion," Equality, Diversity, and Inclusion: An International Journal, Vol. 36 Issue: 2, pp.128-149 https://doi.org/10.1108/EDI-05-2016$\underline{0040}$

Mindra, R., Moya, M., Zuze, L. and Kodongo, O. (2017), "Financial self-efficacy: a determinant of financial inclusion," International Journal of Bank Marketing, Vol. 35 No. 3, pp. 338-353. https://doi.org/10.1108/IJBM-05-2016$\underline{0065}$

Paluri, R, A. \& Mehra, A. (2016), "Financial attitude based segmentation of women in India: an exploratory study, International Journal of Bank Marketing, Vol. 34 No. 5, 2016 pp. 670-689. https://doi.org/10.1108/IJBM-05-2015$\underline{0073}$

Sarma M., \& P.ais, J. (2011). "Financial inclusion and development," Journal of International Development, Vol.23, pp. 613-628. https://doi.org/10.1002/jid.1698

Sekaran, Uma dan Bougie, Roger. 2016. Research Methods for Business. United Kingdom: Jhon Wiley \& Sons Ltd.

Shim, S., Xiao, J. J., Barber, B. L., \& Lyons, A. (2009). Pathways to life success: A conceptual model of financial well-being for young adults. Journal of Applied Developmental Psychology. https://doi.org/10.1016/j.appdev.2009.0 2.003
Swamy, V. (2014). "Financial inclusion, gender dimension, and economic impact on poor households," World Development, Vol. 56, pp.1-15. https://doi.org/10.1016/j.worlddev.2013 .10 .019

World Bank. (2014). Financial Inclusion Data/Global Findex. http://datatopics.worldbank.org/financial inclusion/country/Indonesia

Xiao, J. J. (2008). Applying behavior theories to financial behavior. In J. J. Xiao (Ed.), Handbook of Consumer Finance Research (pp. 69-81). New York: Springer. https://doi.org/10.1007/978-0$\underline{387-75734-6 \quad 5}$

Zach, S., Dobersek, U., Filho, E., Inglis, V. and Tannenbaum, G. (2018), "A metaanalysis of mental imagery affects on post-injury functional mobility, perceived pain, and self-efficacy," Psychology of Sport and Exercise, Vol. 34, January, pp. 79-87. https://doi.org/10.1016/j.psychsport.20 $\underline{17.09 .011}$ 